\title{
NOTES ON THE ANALYSIS OF A CASE OF MELANCHOLIA.
}

\section{By ALFRED CARVER, Birmingham.}

Although much interesting work has been done in elucidating the psychic mechanism in paranoia, relatively little attention has been given to melancholia.* The following notes upon the analysis of a case indicate that in the melancholic we have to do with a mental mechanism which is almost the direct converse of that exhibited by the paranoic.

The subject of this analysis was a woman, age 44. She had always lived a cramped, uneventful suburban life. After marriage at 24 she continued to live within a few minutes' walk of her old home. Her mother died suddenly when the patient was 38. This came as a great shock to her, as the mother had until her marriage been the dominant factor in her life, and even after had continued to secure for her those amenities which she had been too unenterprising to gain for herself. The patient and her husband then went to live at the paternal house, where she acted as housekeeper. Three years later her husband developed diabetes, and she had to nurse him until his death, which took place after about two years. During the last year of her husband's illness she began to become distrait and forgetful, and to exhibit other signs of morbid anxiety, but at the time this did not attract much notice. Immediately after her husband's death she was sent to Harrogate for a rest. There she suffered from severe constipation -described as stoppage. On her return home she became definitely asocial and melancholic; she also developed delusions of poverty and wickedness. The next eighteen months were spent as a resident patient in the houses of three different doctors. At the end of this time she was reported as slightly better, but she still had the same mental symptoms. She complained further of general weakness, and said that whenever she wanted to do anything she felt as if her brains were being stirred up with a spoon. Catamenia were suppressed.

\footnotetext{
* Since writing the above, early in 1920, I have seen in a paper by Dr. Ernest Jones -Recent Advances in.Psycho-analysis - that Professor Freud, during the war, turned his attention to the subject of "Trauer und Melancholie". I have not had access to the original, but from the brief review by Dr. Jones I judge that the following notes are not at variance with Professor Freud's findings, immeasurably though they must fall below them.
} 
There was a haze of albumin in the urine, and blood-pressure was $200 \mathrm{~mm}$. Hg. She had the typical melancholic rigidity and handshake. In other respects nothing abnormal was discovered in her bodily functions. It was at this time that she was referred to me in the hope that analysis might be able to accomplish something where all else had failed.

During the preliminary step of establishing friendly relations and getting her to relate her story as far as she could, I noticed that her great dissatisfaction apparently was directed against herself. She accused herself of being a great cause of trouble to others, acknowledged in exaggerated terms their kindness to her, and "felt furious that she was so damnable". Yet it was noticeable that the outpouring of these accusations against herself, rather than causing distress, gave her relief.

I then began a word-association test, the most important feature of which was the long reaction times on such words as duty, luck, injustice, narrow. Free association on these themes revealed the fact that patient felt herself to be oppressed and wronged by her environment. As an example, the chain of free associations given in response to 'duty' was as follows: "Duty-never done-putting yourself in the background, everything I think of is stopped-I feel as if someone had got me squeezed - one ought to have one's own individualityit is sad-oh, one's surroundings!" In the same way the response to 'luck' began emphatically with "No such thing", but ended up with the plaint, "It just depends what you have got".

Analysis showed that patient was of a frivolous temperament, and that the smaller gaieties and pleasures of life appealed to her. She was fond of the society of men, but expected their esteem as a right rather than as a thing to be won. The death of her husband, in her own estimation, deprived her of her standing and comfort in life, and it was evident that she unconsciously harboured a grudge against him on this account. This was never openly expressed, for, on the contrary, she spoke with exaggerated tenderness about him and heaped all the abuse upon herself. Thus unconsciously she identified herself with her husband. The symptoms of morbid anxiety, which first appeared about a year before his death, came on, as she recalled during the analysis, the very night after she had definitely been given a hopeless prognosis about him.

Unfortunately, during the whole of the analysis, patient only furnished me with two dreams, declaring that she could not remember dreams even when she had them. The first dream was as follows : "I was in a coffin; wanted to get out and throw things off. I thought I was dead, yet knew all the time that I really was not. I woke up in a fright". Analysis showed that this dream expressed patient's 
retirement from the world of action. She blamed her uncongenial environment and her husband's death for forcing this retirement upon her. She wanted the good things of life, considered herself deprived of them, and felt the struggle to remove obstacles to be too difficult, although realizing that but for her inertia she might return to a normal life. The other dream depicted her father as marrying again, and thereby setting her free to go and devote herself to the début of her daughter, who was shortly to leave school. In this dream patient identified herself both with her father and her daughter, and each of them with her husband. Remarriage would do away with the deprivation, but this was opposed by a fixation under the guise of duty. During the analysis it transpired that patient was particularly anxious that her daughter should be saved from the cramping environment in which she herself had grown up. The mental conflict between her desire for freedom and her feeling that duty compelled her to remain in her old environment was severe. Often she expressed it in the phrase, "What is the good of me!" Being good for nothing was in fact a compromise formation which indicated her inability to arrive at a satisfactory solution of the conflict.

Strange to say, the delusions disappeared-probably because they lost their value to the patient-quite early during treatment. The delusion of poverty appeared merely to excuse patient from attempt- 0 ing actively to break away from the surroundings which she abusedo so lavishly. Thus, if she lacked money she must perforce remain passive and submissive to those upon whom she was dependento Perhaps also a poverty of spirit was being symbolized. Actually; though not wealthy, she had been left comfortably provided for quite apart from financial aid by her father. The delusion of wickedness was over-determined. It seemed primarily to have arisen from repressed desires to break away from the conventions in which she had been brought up. Another factor was the unconscious grudge which she bore her husband for deprivations which his death had brought upon her. Secondarily it came to have value as an explanation-rationalization-of the cause of her condition. Thus, "If I am in this awful state it must be a punishment for my sins".

The mental mechanism in the above case seems to be a displacement of the reproach from the environment, including the husband, to the self ; analysis showing that the abuse which the patient heaped so lavishly upon herself was really intended for the former, which she considered to be wronging her. Hence the abuse of herself was well borne ; indeed, it even gave her a certain satisfaction. At the same time the reproach and the depression were in a sense justified, for it was her own fault that she made so poor an effort to cope with the depression into which the deprivation had thrown her. The displace- 
ment further served as a defence against any reproach which others might level against her, for whatever the latter might say they could not accuse her of anything more than that which she herself constantly reiterated. In this way she completely disarmed criticism, and any attempt to coerce her was met by a mule-like accentuation of symptoms. The mechanism demonstrated in this case may be described as introjection, and is diametrically opposed to that of projection, which is characteristic of the paranoic. The melancholia, as revealed by withdrawal of interest in life and mental and physical inertia, corresponds to the patient's refusal to adapt herself after a deprivation, or to continue the struggle with disagreeable circumstances which she considered to have wronged her. It is as though a sulky child from whom a particular toy had been taken declared that she would never play again any more.

The patient's earlier history served to explain her general attitude to life, and why, when deprived of what she desired, she responded by this particular neurotic regression rather than another. Apparently the melancholic has a poorly-developed ego-ideal, in this respect again presenting an antithesis of the paranoic. The paranoic, by projection, externalizes his conscience, while the melancholic, by introjection, heaps upon himself all the abuse that is really intended for his environment, including the loved person. The melancholic thus behaves more like a sulky child when deprived of the gratification of his narcissistic libido, his conscience being less developed than is that of the paranoic, the specification of whose ego-ideal is higher.

The following extraneous aids were made use of during the analysis. In the early stages the patient, not being in an acute condition, was encouraged to do certain small tasks which were obviously within her power; such, for example, as five-finger exercises. These were gradually increased until she could play the piano as well as formerly. It was exceedingly important in all these graduated exercises that she should agree at every step that she was able to perform the task set, and to this end the task or its increment had to be so obviously within her power that she could not refuse it.

The course of the analysis was deliberately interrupted about every six weeks, for a few days, during which the patient was sent away with her companion for a holiday. The object of this procedure was to aid her by relieving the monotony of her environment, and to keep her in touch with things which really appealed to her, and thus if possible prevent her from settling down into an absolutely chronic state in which all interest was lost. On the first two of these holidays she went apathetically; even unwillingly, but subsequently she manifested an interest in them and began to collaborate in making up a 
programme. At this time also her catamenia reappeared, and have remained regular ever since.

It is not claimed that the mechanism revealed in this case is demonstrable in, or can account for, all so-called melancholic conditions; but I consider it worth reporting, for other cases also have led me to believe that the underlying factor in melancholia is a failure of readaptation to an environment which, owing to a certain deprivation, has been rendered devoid of interest. Individuals with what, for want of a better expression, may be termed a sulky character, respond to this neurotically by a physical and mental inertia, and defend themselves by displacing the reproach from the environment to the ego. There is further an identification of the self with a beloved person who is blamed for having caused the deprivation.

Associated delusions, if present, are of small moment; and of all the psychogenetic psychoses melancholia is the most amenable to treatment, though in view of the frequency of relapses one is not justified in speaking of a cure. 